\title{
THE INFLUENCE OF PREMEDICATION WITH NARCOTICS AND BELLADONNA ON OXYGENATION IN CARDIAC SURGERY PATIENTS*
}

\author{
K.W. TƯngull, B.A.SC., M.D. $\nmid$ AND R.T. MiYaishima, E.A., M.D. $\downarrow$
}

Premeication with narcotics and/or belladonna drugs has been shown by some authors ${ }^{1,2,9}$ to lead to a significant decrease in arterial oxygen tension. Others have suggested that oxygenation is not compromised with combinations of barbiturate and belladonna ${ }^{4}$ (pentobarbital and atropine), barbiturate alone ${ }^{5}$ (pentobarbita]) or narcotic and belladonna (morphine and scopolamine). Although some studies have shown that atropine caused no significant change in oxygenation in healthy volunteers, "others have demonstrated that atropine decreased arterial oxygen saturation significantly. ${ }^{2, T}$ The present study is an attempt to re-evaluate the effects of narcotic and belladonna premedication on oxygenation in ambulatory patients prior to cardiac surgery, by measuring arterial oxygen tensions and alveolar-arterial gas tension gradients.

\section{Materials and Methods}

Fifteen patients were studied. They were clinically free of chest disease or overt uncontrolled congestive heart failure, with the exception of one (case $\mathrm{No}, 7$ ). Thirteen were candidates for coronary artery bypass graft procedures for refractory or intractable angina pectoris; one (No. 7) was a candidate for mitral and aortic valve replacement because of refractory congestive heart failure and the remaining one (No. 11) was a candidate for aortic valve replacement. The clinical details are shown in Table $\mathrm{I}$.

All patients were seen 24 hours preoperatively. When the end-tidal carbon dioxide concentration had been constant for 10 to 15 minutes, blood samples were taken from the radial or femoral artery with the patient in the supine position. The patients breathed room air for 10 to 15 minutes, the samples were taken and the sequence was repeated using 100 per cent oxygen. The patients were premedicated on the day of operation with morphine (approximately $0.15 \mathrm{mg} / \mathrm{kg}$ ) or meperidine (approximately $15 \mathrm{mg} / \mathrm{kg}$ ) and either atropine or scopolamine as shown in Table I. Arterial samples were collected from brachial artery catheters one hour after premedication while the patients were awake and supine. They breathed room air for 10 to 15 mimutes and then 100 per cent oxygen for 10 to 15 minutes. In all instances the end-tidal carbon dioxide concentrations were maintained for at least 10 to 15 minutes.

-Presented at Canadian Anasthetists' Society Annual Meeting, Hafifax, June, 1972.

fClinical Research Fellow (Pulmonary Disease), St. Paul's Hospital, Vancouver British Columbia.

tClinical Associate Professor (Surgery), University of British Columbia and St. Paul's Hospital.

639

Canad. Anaesth. Soe. J., volr 19 , no. $6_{r}$ November 1972 
TABLE I

Detalls of Patients Studied

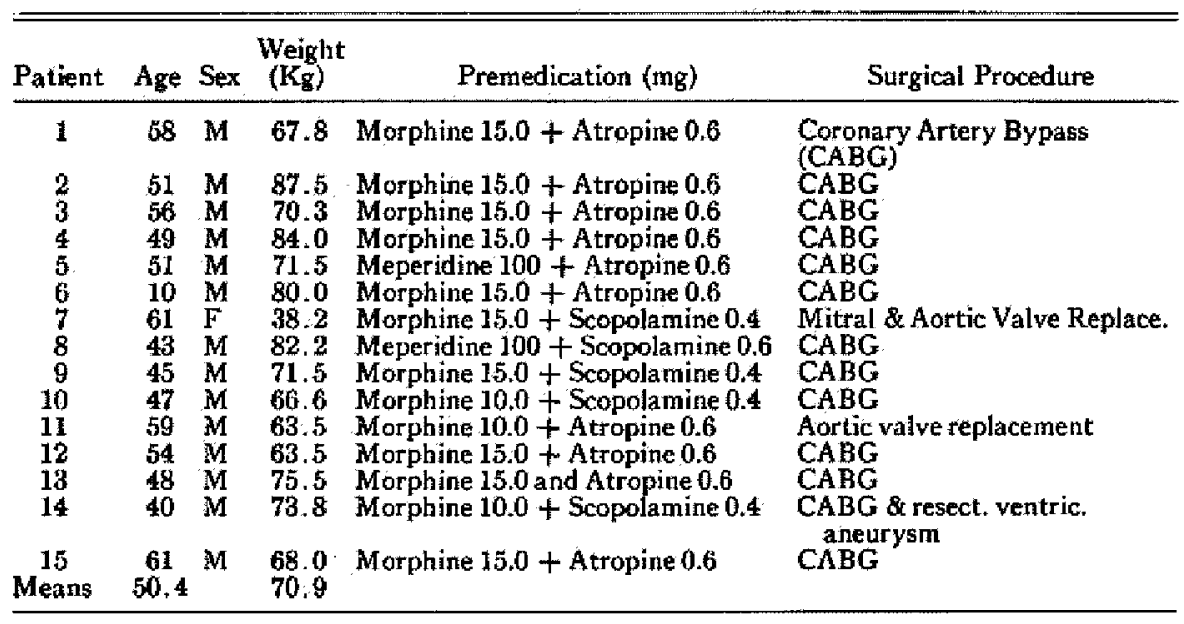

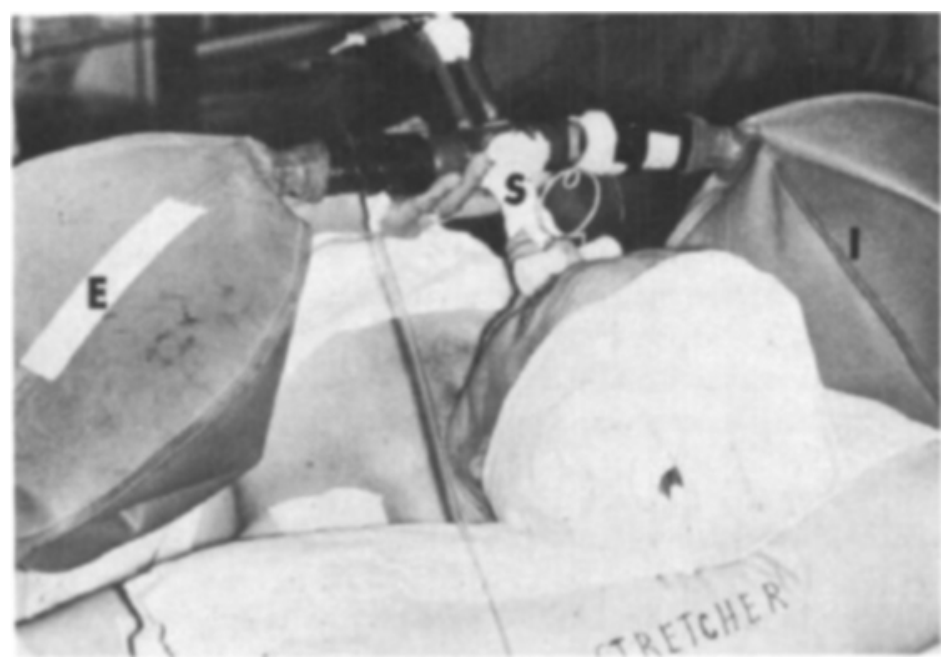

Frcure 1. Rahn-Otis End-Tidal Sampler (S) with Inspired (I) and Expired (E) collection bags and plastic tubing ( $T$ ) which connects to the meters.

Collection of end-expiratory and mixed expiratory gas samples was done with a Rahn-Otis End-Tidal Sampler and a baffled (expiratory) 15-litre rubber bag as shown in Figure 1. Continuous measurements of the end-expiratory and mixed expired gases were obtained using a Beckman $\mathrm{CO}_{2}$ Analyzer and a Beckman Oxygen Analyzer connected in series. A Beckman micro-catheter sample pump moved the $200 \mathrm{ce}$ sample through a constant length of plastic tubing from the EndTidal Sampler or expiratory bag through the meters. The meters were precalibrated with gases analyzed by the Scholander method. 
TABLE II

Arterlal oxygen Tensions at Low and High Alveolar oxygen Levels

\begin{tabular}{|c|c|c|c|c|}
\hline \multirow[b]{2}{*}{ Patient } & \multicolumn{2}{|c|}{$\mathrm{Pa}_{2}$ on Room Air (mmHg) } & \multicolumn{2}{|c|}{$\mathrm{PaO}_{0_{2}}$ on 100 per cent Oxygen $\left(\mathrm{mmH}_{\mathrm{g}}\right)$} \\
\hline & $a$ & $b$ & a & $b$ \\
\hline 1 & 75.5 & 97.0 & 350 & 380 \\
\hline 2 & 96.5 & 69.2 & 400 & 308 \\
\hline 3 & 93.5 & 105.2 & 540 & 402 \\
\hline 4 & 75.2 & 85.5 & 525 & 590 \\
\hline 5 & 89.2 & 95.0 & 380 & 440 \\
\hline 6 & 92.0 & 90.0 & 610 & 405 \\
\hline 7 & 104.2 & 105.0 & 505 & 365 \\
\hline 8 & 104,0 & 100.0 & 585 & 565 \\
\hline 9 & 105.2 & 105.0 & 548 & 500 \\
\hline 10 & 105.2 & 93.0 & 545 & 460 \\
\hline i) & 89.0 & 99.0 & 510 & 555 \\
\hline 12 & 93.8 & 98.0 & 420 & 550 \\
\hline 13 & 75.5 & 96.0 & 470 & 450 \\
\hline 14 & 93.5 & 85,5 & 545 & $5 \mathrm{40}$ \\
\hline 15 & 80.0 & 85.0 & 440 & 480 \\
\hline
\end{tabular}

$a=$ before premedication.

$b=$ after premedication.

Tidal volumes were measured preoperatively with a Collins 9 litre spirometer while a Wright's Respirometer, precalibrated with the Collins spirometer, was used in the operating room.

Blood samples were taken in heparinized glass syringes, immediately iced and placed in a refrigerator at 4 degrees Centigrade $\left({ }^{\circ} \mathrm{C}\right)$. Analysis was done within 30 minutes. Blood gas tensions and $\mathrm{pH}$ were measured with a Radiometer $\mathrm{pH} /$ Blood Gas Monitor and Microelectrode Unit at $37^{\circ} \mathrm{C}$. Calibration of this apparatus was done before and after each set of determinations. Severinghaus correction factors for body temperature and blood $\mathrm{pH}$ were utilized when determining percent saturation of haemoglobin $\left(\mathrm{SaO}_{3}\right.$ ) from the arterial oxygen tension. ${ }^{8}$

The mean end-tidal oxygen and carbon dioxide concentrations of the respiratory cycle corresponding to the blood sampling period were assumed to equal the alveolar oxygen and alveolar carbon dioxide concentrations. ${ }^{9}$ These values were used to calculate the Alveolar-arterial oxygen gradients ( $\mathrm{A}$-aDOr. $)$ and the arterialAlveolar carbon dioxide gradients $\left(\mathrm{a}-\mathrm{ADCO}_{2}\right.$ ) after allowance was made for ambient barometric and water vapour pressures. Dead space-tidal volume ratios $\left(V_{D} / V_{T}\right)$ were based on the Riley modification of the Bohr equation ${ }^{10}$ substituting arterial carbon dioxide $\left(\mathrm{PaCO}_{2}\right)$ for the "ideal" alveolar $\mathrm{PCO}_{2,}$, The statistical evaluations were based on the paired two-tail t-test ("Student t-test").

\section{REsuLts}

Arterial oxygen tension was generally increased after premedication when the patients were breathing room air and 100 per cent oxygen, as shown in Tables II and III. There was wide individual variation (see Table II) in the $\mathrm{PaO}_{2}$ when the patients were breathing 100 per cent oxygen. Alveolar-arterial oxygen gradients $\left(\mathrm{A}-\mathrm{aDO} \mathrm{O}_{2}\right)$ of subjects breathing room air were decreased after premedication, 
while $\mathrm{A}-\mathrm{aDO}$ remained the same with 100 per cent oxygen and premedication. Alveolar and arterial carbon dioxide tensions $\left(\mathrm{PACO}_{2}\right.$ and $\mathrm{PaCO}_{2}$ respectively) showed slight hyperventilation prior to premedication. Large tidal volumes $\left(\mathrm{V}_{\mathrm{T}}\right)$ of 600 to $700 \mathrm{ml}$ were the rule in this study. Arterial-alveolar carbon dioxide gradients $\left(\mathrm{a}-\mathrm{ADCO}_{2}\right)$ were significantly increased with premedication and 100 per cent oxygen. Arterial $\mathrm{pH}\left(\mathrm{p}_{\mathrm{a}} \mathrm{H}\right)$ was unchanged with changes in inspired oxygen but significantly decreased with premedication. Premedication was followed by $\mathrm{PaCO}_{2}$ values within the range of normal ( 38.4 to $39.4 \mathrm{~mm} \mathrm{Hg}$ ) suggesting that ventilation was not depressed by the doses of narcotics used in these patients. Significant increases in dead space/tidal volume ratios $\left(V_{\mathrm{V}} / \mathrm{V}_{\mathrm{T}}\right)$ occurred with changes in inspired oxygen. Premedication itself did not significantly alter the $V_{D} / V_{T}$ ratios.

\section{Disctussion}

The combination of narcotic and belladonna premedication has not been recently studied in cardiac surgery patients. The reason for this lack of study may be the possibility that atropine or scopolamine may cause detrimental arrhythmias and onset of angina or congestive cardiac failure. ${ }^{11}$ Combinations of these drugs are commonly used in this hospital and a ready pool of subjects was available. Electrocardiographic monitoring revealed no arrhythmias 30 to 60 minutes after premedication, nor did any subject admit to any discomfort after premedication.

Ambulatory healthy volunteers given atropine intravenously do not get a significant decrease in $\mathrm{PaO}_{2}$ or $\mathrm{SaO}_{2}{ }^{*}$ Other studies have shown hypoxaemia in patients given cither subcutaneous or intramuscular atropine $\mathrm{e}^{2,7}$ or narcotic-belladonna combinations..$^{*}$ Some of these studies were based on measurement of oxygen saturation $^{2.3}$ and omitted arterial samples prior to premedication. These two factors could yield significant errors. A more recent study including arterial samples 24 hours preoperatively showed a significant decrease in $\mathrm{PaO}_{2}$ and $\mathrm{SaO}_{2}$ when a combination of meperidine, promethazine and pentobarbital was used." Another recent study has shown the preoperative oxygenation was maintained when morphine and scopolamine were used. Pulmonary gas exchange was found adequate in this latter study $\mathrm{y}^{4}$ and alveolar-arterial gas tensions were not assessed.

Significant hypoxaemia did not occur in this study. Possible causes of hypoxaemia in these subjects include changes in ventilation or physiological dead space, changes in perfusion, changes in the matching of ventilation to perfusion ( $\dot{\mathrm{V}} / \dot{Q}$ ) and changes in right-to-left shunting or venous admixture. The presence of a significant decrease of $\mathrm{A}-\mathrm{aDO}_{2}$ gradients on room air and the lack of an increase of $\mathrm{A}-\mathrm{aDO} \mathrm{O}_{2}$ gradients on 100 per cent oxygen effectively eliminates right to left shunts or venous admixture as a possible cause of hypoxaemia ${ }^{12}$ after premedication. The presence of slight but significant ventilation-perfusion $(\dot{\mathrm{V}} / \dot{Q})$ abnormalities is supported by the a-ADCO ${ }_{2}$ gradients ${ }^{13,14}$ which were increased significantly above the accepted normal value of $1 \mathrm{~mm} \mathrm{Hg}{ }^{15}$ and the slightly increased alveolar oxygen tensions ${ }^{16}$ when the subjects were breathing room air. These gradients confirm that distribution of ventilation is changed with premedication, but the lack of increase in $\mathrm{A}-\mathrm{aDO} \mathrm{D}_{2}$ suggests that the magnitude of these $\dot{\mathrm{V}} / \dot{\mathrm{Q}}$ changes must be limited. Further support for the minimal changes in $\dot{V} / \dot{Q}$ is shown by the per- 
sistence of the $V_{D} / V_{T}$ ratio increase which occurs with 100 per cent oxygen ${ }^{17}$ despite the narcotic-belladonna premedication. ${ }^{18}$

The age distribution and the ambulatory status of the subjects in this study are important determinants of oxygenation. Narcotic and belladonna premedication in the older and/or bedridden patient may predispose to atelectasis and shunting secondary to inadequate "sighs," inadequate clearing of secretion and inactivity ${ }^{10.20}$ All these factors may tend to increase atelectasis and give rise to increased shunting or $\dot{\mathrm{V}} / \dot{Q}$ abnormalities with hypoxaemia as the end result, 19,20,21 Large tidal volumes without "sighs," as seen in this study, tend to prevent atelectasis ${ }^{20}$ and thus prevent shunting and hypoxaemia.

\section{ConCluston}

This study shows that combined narcotic-belladonna premedication in the ambulatory cardiac patient will maintain adequate arterial oxygen tension and unchanged arterial oxygen saturation despite slight increases in ventilation-perfusion abnormalities after premedication. Compromised oxygenation is probably uncommon in ambulatory cardiac patients premedicated with judicious doses of narcoticbelladonna combinations.

\section{SUMMAFY}

The influence on oxygenation of premedication with mixtures of narcotic and belladonna drugs was assessed in 15 cardiac surgery patients. With the subjects breathing room air and then 100 per cent oxygen, comparisons were made of preoperative measurements of arterial oxygen tension, carbon dioxide tension and $\mathrm{pH}$. The same parameters were measured one hour after premedication using morphine $0.15 \mathrm{mg} / \mathrm{kg}$ or meperidine $1.5 \mathrm{mg} / \mathrm{kg}$ in combinations with atropine 0.6 $\mathrm{mg}$ or scopolamine 0.4 or $0.6 \mathrm{mg}$. End-tidal carbon dioxide and oxygen tensions were measured in all cases to evaluate alveolar-arterial oxygen $\left(\mathrm{A}-\mathrm{aDO} \mathrm{O}_{2}\right)$ and carbon dioxide gradients (a-ADCO${ }_{2}$ ). The results show a significant increase in $\mathrm{PaO}_{2}$ after premedication, with a slight decrease in $\mathrm{pH}$ and no significant change in arterial oxygen saturation. $\mathrm{A}-\mathrm{aDO}$ 2 gradients did not increase significantly with premedication suggesting that increased right to left shunting did not occur. Changes in a- $\mathrm{ADCO}_{2}$ ratios indicated slight but significant ventilation-perfusion changes but they were not large enough to decrease arterial oxygenation. Dead space tidal volume ratios $\left(V_{\mathrm{D}} / \mathrm{V}_{\mathrm{T}}\right)$ did not change after premedication but did alter markedly with increased oxygen. All subjects exhibited large tidal volumes and this may have been a factor in prevention of shunting by prevention of atelectasis. The ages and ambulatory status of this group were key factors.

This study shows that narcotic-belladonna premedication does not compromise oxygenation of the ambulatory cardiac surgery patient when tused in judicious doses.

\section{RÉSUMÉ}

Nous avons évalué, chez 15 malades devant subir une chirurgie cardiaque, les effets de la prémédication aux narcotiques et à la belladone. Nous avons mesuré, 
en cours d'opération, la tension d'oxygène artérielle, la tension de $\mathrm{CO}_{2}$ et le $\mathrm{pH}$ alors que les malades respiraient l'air de la salle et, plus tard, de l'oxygène à 100 pour cent et nous avons comparé les données. Nous avons mesuré les mêmes paramêtres une heure après la prémédication consistant en morphine $0.15 \mathrm{mgs} / \mathrm{Kg}$ ou en mépéridine $1.5 \mathrm{mgs} / \mathrm{Kg}$ associé l'atrophine $0.6 \mathrm{mgs}$ scopolamine $0.4-0.6 \mathrm{mg}$. Nous avons mesuré les tensions d'oxygène et de $\mathrm{CO}_{2}$ de fin d'expiration chez tous les malades pour évaluer les gradients d'oxygène et de $\mathrm{CO}_{2}$ alvéolo-artériels $\left(\mathrm{A}-\mathrm{aDO} \mathrm{O}_{2}\right)$ et $\left(\mathrm{a}-\mathrm{ADCO}_{2}\right)$. Les résultats ont démontré une augmentation importante de la $\mathrm{PaO}_{2}$ après la prémédication et une légère diminution du $\mathrm{pH}$ et peu de changement de la saturation artérielle en oxygène. Le gradient $\left(\mathrm{A}-\mathrm{aDO} \mathrm{O}_{2}\right)$ n'a pas changé de façon importante après la prémédication faisant penser qu'il n'est pas survenu d'augmentation de shunt de droite a gauche. Les changements des rapports (a- $\mathrm{ADCO}$ ) démontrent de légers mais significatifs changements mais pas assez importants pour diminuer l'oxygénation artérielle. Les rapports espace mort/ air courant $\left(\mathrm{V}_{\mathrm{D}} / \mathrm{V}_{\mathrm{T}}\right)$ n'ont pas changé après la prémédication, mais ils se sont modifićs de façon marquée avec l'augmentation de l'oxygène. Tous les sujets ont présenté un air courant augmenté et cela peut avoir été un facteur de prévention du shunt en prévenant l'atélectasie. Les facteurs importants chez ces malades ont été l’âge et l'état ambulatoire.

Cette étude démontre que la prémédication narcotique-belladone, employée à des doses judicleuses, ne compromet pas l'oxygénation du malade ambulant candidat a la chirurgie cardiaque.

\section{ACKNOWLEDGMENT}

The financial support of the Tuberculosis and Chest Disabled Veterans'Association is gratefully acknowledged.

\section{REFERENCES}

1. KEATs, A.S. \& Gnigis, K.7. Respiratory depression associated with relief of pain by narcotics. Anesthesiology 29: 1006 (1968).

2. Tomlin, P.J., Conwax, C.M., \& Payne, J.P, Hypoxaemia due to atropine. Lancet, 1, i4, 1964.

3. DODKIN, A.B. SONE, $Y$. The effect of methoxylurane-nitrous oxide anesthesia on arterial

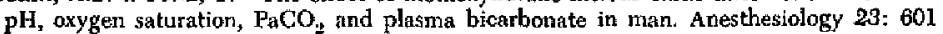
(1962).

4. Mattivez, L.R. Von Euleg, C., \& Nohlanden, O.P. Ventilatory exebange and aeid-base balance before and after preoperativg medication. Acta Amasth. Scandinav. $I 1: 139$ (1967).

5. Pience, J.A. \& Garofnlo, M.L. Preoperative medication and its effect on blood gases. J.A.M.A. 194: 99 (1965).

6. FINCH, IS. Zstgarond, E.K, \& DeKonnfelo, T.I. Arturial blood gases after atropine sulphate in healthy volunteers. Lancet 11 (Octobcr 1969).

7. Conway, C.M. Arterial oxygen tensions in surgical patients in Payne, J.P. and Hill, D.W. (eds). Oxygen measurements in blond and tissues and their significance. Boston: Little, Brown, $173-186$ ( 1966 )

8. Severunghaus, J,W, Oxyhemoglobin dissociation curve correction for temperature and pH variation in human blood. J. Appl, Physiol. 12: 485 (1964).

9. RAHs, $H$. A concept of mean alveolar air and the ventilation-blood flow relationship during pulmonary gas exchange. Am. J. Physiol. 158: 21 (1949). 
10. Riley, R.L., Lujenthal, J.L., Prommex, D.D., \& Frankg, R.E. On the determination of the physiologically effective pressures of pxygen and carbon dioxide in alveolar air. Am. J. Physiol. I\&?: 191 (1946).

11. EGER, E. Atropine, scopolamine and related compounds. Anesthesiology 23: 365 (1968).

12. NUNw, J.F. Applied respiratory physiology, London: Butterworths, 337-346 (1969).

13. LENFANT, $C$. Arterial-alveolar differente in $\mathrm{PCO}_{2}$ during air and oxygen brenthing. $\mathrm{J}$. of Applied Physiol, 21: 1356 (1966).

14. Askroc, V. Changes in (a-A) $\mathrm{CO}_{2}$ difference and pulnonary artery pressure in anaesthetized man. J. of Applied Physiol. 21 : 1298 (1966)

15. STEPHEN, G.W., BANNER, M.P., WOLCMAN, H., \& SMrTh, T.C. Respiratory pharmicology of mixtures of scopolanine with secobarbital and with fentanyl. Anesthesiology 31: 237 (1969).

16. FENN, W,O. \& RAkN, H. (seetion eds). Handbook of physiology, section 3: respiration, vol, 1, Washington, Waverly Press, 693: 736 (1964).

17. SYKes, M.K. \& FinLa X, W.E.I. Dead space during anaesthesia-effect of added oxygen. Anaesthesia 26: 22 (1971).

18. TuRnulul, K.W. Dead space after added oxygen and premedication with narcotics and bellidonnas. Canad. Anaes. Soc. J. Sept. 1971, in press.

19. ECISErr, L.D. \& BENDIXEN, H.H. Effect of morphine on breathing pattern, J.A.M.A. 88: 485 ( 1964 ).

20. NUw, J.F. Influenoe of age and other factors in hypoxaemia in the postoperative period. Lancet 2; 466 (1965)

21. WEST, J.B. Ventilation, blood flow and gas exchange. Oxford, Blackwell (1965). 